\title{
CITIES AS CENTRES OF CREATIVITY IN THE EAST-CENTRAL EUROPEAN NATION BUILDING
}

\author{
Béla MESTER * \\ Hungarian Academy of Sciences, Research Centre for the Humanities, Institute of Philosophy \\ 4 Tóth Kálmán Str., 1097 Budapest, Hungary
}

Received 30 November 2017; accepted 09 June 2018

\begin{abstract}
This paper offers an overview of the philosophical reflections for the change of structure of the scholar public sphere in the 18th and 19th centuries, focussed on the Hungarian examples, with the idea of urbanity in the centre. After the overview of the Scottish Enlightenment, and the Kantian and Herderian approaches, it will be discussed the Hungarian case, within and after the controversy on Immanuel Kant (1792-1822). The topic of urbanitas was often touched both as an ideal-typical environment of the philosophical activity, and the real environment of the authors under conditions of an industrialised machinery of the cultural production. The next topic is the specific features of the same turn of the structure of the scholar communication in East-Central Europe, where the change of the languages of the publications has characteristic consequences and the gap between the spheres of the school philosophy and the public philosophy was deeper. The features of the specialities of the philosophies of East-Central Europe in their self-understanding within the new context after the communicational turn is the last topic, focussed on the Hungarian case, especially on the usage of the concept of urbanity in the Hungarian creative discourse about the public philosophy, and national philosophy.
\end{abstract}

Keywords: East-Central Europe, Hungarian philosophy, national philosophy, public philosophy, urban sphere, urbanity.

\section{Introduction: the idea of urbanity in the history of philosophy}

Philosophical usage of the terms related to the city and urbanism has a twofold structure. Urban culture is a neutral, descriptive term of a type of the human communities as bases of a peculiar form of the intellectual life; urbane culture, or urbanity are expressions of values. In the antique tradition, the distinction between the urban and rural form of the societal life is fundamental; we should remember the usage of the twin categories of polis and ethnos in Aristotle's Politics:

"Now the city [polis] is made up not only a number of human beings, but also of those differing in kind: a city [polis] does not arise from persons who are similar. A city

\footnotetext{
${ }^{\star}$ Corresponding author. E-mail: mester.bela@btk.mta.hu
} 
[polis] differs from an alliance. The latter is useful by its quantity even if its parts are the same in kind (since an alliance exists by nature from mutual assistance) and when a greater weight is added to the scale. In this short of way, too, a city [polis] differs from a nation [ethnos], when the multitude is not scattered in villages but rather is like the Arcadians" (2013, p. 26).

The meaning of these Aristotelian twin-terms is not clear from every respect, if we consult the English translation, only. Modern cities, being parts of a bigger political community, are not equivalents of the antique polis; and modern nations as sovereign political communities are not equivalents of the antique ethnos, as well. However, the whole of the field of meaning of these antique terms cannot be explained precisely in any modern language; a comparison with the vocabulary of a 19th-century German translation will be probably useful for our endeavour to better understanding of the original text. May be, the German term Staat for polis, and Völkerschaft for ethnos are closer to the Aristotelian meaning of his Greek words (Aristoteles, 1872, pp. 55-56). In Aristotle's thought, polis, or, the well-formed city is a prerequisite of the political activity of its citizens, offers an opportunity for practicing their virtues, and ultimately for their eudemonia. Ethnos, a typical community of the Arcadian shepherds has not any idyllic attitude; it is a feature of the structure of the life of the inland barbarians, similar to the amorphous societies of the real barbarians under rule of their tyrants.

Urban life as a prerequisite of the emergence of the philosophical thought has appeared as early time as the first references to the lifestyle of Socrates as an intellectual model; the typical urban personality of this figure of the downtown of Athens has linked with the concept of the philosophical thought in the cultural memory of the tradition of Western philosophy. As Cicero has formulated it:

"[N]umbers and motions, and the beginning and end of all things, were the subjects of the ancient philosophy down to Socrates, who was a pupil of Archelaus, who had been the disciple of Anaxagoras. These made diligent inquiry into the magnitude of the stars, their distances, courses, and all that relates to the heavens. But Socrates was the first who brought down philosophy from the heavens, placed it in cities, introduced it into families, and obliged it to examine into life and morals, and good and evil" (1877, p. 166, my italics) ${ }^{1}$.

This tradition of interpretation of the philosophical thought as an urban phenomenon has become characteristic in the early modernity. There is an often quoted scene of the novel of Virginia Woolf, entitled Orlando: A Biography, for characterising the new urban atmosphere of the everyday intellectual activity of the citizens. It is the arrival of the heroine of the novel to the atmosphere of "urban glories" of the 18th-century London, in a "fine September morning":

"the ship sailed to its anchorage by London Bridge than glance at coffee-house windows where, on balconies, since the weather was fine, a great number of decent citizens sat at ease, with china dishes in front of them, clay pipes by their sides, while one

\footnotetext{
${ }^{1}$ In Latin: "[A]b antiqua philosophia usque ad Socratem, qui Archelaum, Anaxagorae discipulum, audierat, numeri motusque tractabantur, et unde omnia orerentur quove reciderent, studioseque ab is siderum magnitudines intervalla cursus anquirebantur et cuncta caelestia. Socrates autem primus philosophiam devocavit e caelo et in urbibus conlocavit et in domus etiam introduxit et coegit de vita et moribus rebusque bonis et malis quaerere", Tusculanae disputationis, Liber V, IV, 10 (1853, p. 399, my italics).
} 
among them read from a news sheet, and was frequently interrupted by the laughter or the comments of the others" (Woolf, 2006, pp. 123-124).

This picture mirrors all the features of the early modern representation of the urbanity. The fine material of the cups and pipes symbolise the technical civilisation and its positive influence for the everyday life; periodicals are the signs of the boom of the press industry and its influence for the everyday thinking; sharing and discussing of their contents is a method of a conscious, reflective collectiveness of the societal thinking. The values of the urbanity shown by this picture are clear in a comparison with its hidden opposite, a scene with men with wooden cups of beer in the darkness of a rural inn who are listening the balladry of a municipal fiddler, as John Milton has described this segment of the oral communication subjected by the written elite culture ironically in his Areopagitica (for an analysis of this locus of Milton see Mester, 2010). This new urbanity of the early modern thinking is reflected, individual and linked with the technology because of its basis in the printed texts; and it is collective in the same time, because of the continuous discussion of the individuals.

\section{A turn of the public sphere}

The structure of the scholar public sphere of the Central-European philosophical life has fundamentally changed in the turn of the 18th and 19th centuries, following the similar, but earlier changes of the British and French philosophies. This new structure of the scholar public sphere was characterised by two features: a relative independence from the institutional network of the universities, based on the increased significance of the independent publishing houses and scholar periodicals; the increased significance of the usage of the native vernaculars in philosophy, instead of Latin. However, the change of languages had fundamental consequences in the self-understanding of the next generation, and in the history of philosophy, its importance was not conscious in the contemporary discourse in any time. However, the change of the dominant languages of the philosophical publications has happened in different epochs in different national cultures, but always relatively quickly (within a generation in the Hungarian case), participants of this change could interpret their positions within the framework of the functionally bilingual communication of the early modernity, applied its term for the actual personal and regional circumstances. Let us offer several examples for this functional bilingualism. John Locke has used mainly Latin works of the foreign literature and neglected their English translations on the one hand; and has written his works in English, excluding his A Letter Concerning Toleration (in Latin: Epistola de tolerantia, for its first edition see Locke, 1689), on the other (for a standard analysis of the catalogue of Locke's library, see Harrison \& Laslett, 1971).

A Dutch professor of philosophy and mathematics, with German origin in Utrecht, Johann Friedrich Hennert (1733-1813) as a follower of the Scottish common sense tradition, has read the philosophical literature in English, has published the majority of his own most serious philosophical works in Latin (e.g. Hennert, 1781) by the academic standards of the late 18th-century Netherlands. The list of Hennert's book contains 37 items by the evidence of the catalogue of the Utrecht University Library (they are his monographs, only, including his translations). 11 items were written in Latin, all of them academic works, linked to his 
university praxis. 18 items are in Dutch, a lot of them published by the Royal Netherlands Academy of Arts and Sciences, several items are Dutch translations of his previous Latin works. There are only four Dutch items with philosophical topics; one of them his translation of James Beattie's main work from English, the other one is his moral philosophy with a bilingual (Dutch-Latin) frontispiece, and, probably, bilingual content, the third one is a translation of one of his originally Latin university courses, and the fourth one, however, the original Latin title is missing, is probably the same case. 7 items are written in French, all of them connected with the controversies in natural sciences in his lifetime: about comets, and so on. Only one item was published in German, it is a translation of his Latin work on mathematics.

At the same time, Kant has used French translations in his readings, has written his own works in German, excluding four obligatory treatises for achieving university degrees (1902a, 1902b, 1902c, 1905). Several years later, a protagonist of the Hungarian debate on Kant, József Rozgonyi, Hennert's disciple in Utrecht, has written all his strictly academic works in Latin, based on English, French and German literature, and used his native Hungarian for popular works, a series of short philosophical pamphlets, only (Rozgonyi, 1792, 1819). The usage of the native and Latin languages was linked with different audiences, divided to academic and laic, home and foreign public spheres. The authors who were parts and participants of this change, has reflected usually on its one feature, only. In the following it will be offered the outlines of the main typical theoretical reflections of the British, German and the EastCentral European cultures.

\section{Reflections to the urbanity of thought in the British philosophy, and their continental influence; interpretation of the urban public sphere in the German Populärphilosophie}

This new image of the urbane thinking has emerged as a new interpretation of the role and value of the common sense, at first in the British philosophy. The Stoic term koine einoia, Latinised as sensus communis by Cicero (1822, III. 1, pp. 195, 284-285), has been an often quoted expression of the British philosophical literature from Earl of Shaftesbury (1737) to Thomas Reid (1710-1796) (see especially the second chapter of his Essay on Judgement, entitled "Common Sense", with a reference to the above mentioned locus of Cicero (Reid, 1786, pp. 195-210)), throughout in the epistemology, moral and political philosophies, and in the aesthetical discourse. The original meaning of this concept is an intrinsic faculty of every human individual, what appears in their understanding, moral judgements and sentiments, and in their taste about artworks. Community of this faculty has appeared just as a uniform feature of individual minds, in the initial form of this term. The new interpretation of the common sense emphasises the needed development of this inborn human faculty in a common societal environment. By a parallelism of the moral philosophy of Adam Smith (1976), our moral sentiments, which can be regarded as a special form of the common sense, are intrinsic individual features on the one hand, but the achievement of a level of the humanity, in which we can realise and recognise the common roots of our moral judgements, depends on the really global commercial, economical and, at the same time, moral and po- 
litical interaction of the humanity. Similar chains of ideas have followed the frequent usage of the terms of politeness, refinement, and taste, sometimes in the core of epistemology, but more often in the political, aesthetical and moral discourses, amongst the authors of the Scottish Enlightenment (SE).

It is not an accident event of the history of philosophy that this theoretical reflection has emerged firstly and strongly in Scotland; it can be interpreted as an answer for a turn in the structure of the communication, under conditions of the rising of the modernity, linked with the urbanism, and their consequences for the intellectual sphere, especially for the philosophical life. Semi-peripheral position of Scotland has offered a good point of view for detecting the structural changes; several processes were realised easier from an Edinburgh perspective than from London. The usage of the antique common sense tradition out of the epistemology as a philosophical discipline, and its application for the moral and political philosophies, and for aesthetics, as well, has two roots in the Scottish intellectual environment; however, it was not far from the original antique version, as well. First of them is a usual professorship of ethics in a highly extended meaning, in the university system of Scotland, the second one is the new possibility of a public philosophy for a relatively large, and educated audience.

For a symptomatic example of the linked aesthetical and epistemological common sense see Reid's Essays on the Intellectual Powers of Man (1786, p. 206). Reid here quotes the concept of sensus communis formulated by Cicero in Latin, without English translation ${ }^{2}$.

Cicero here speaks about our common faculty to make an aesthetical judgement of a rhythm of a rhetoric text, and its performance. Reid has discussed the common human mathematical knowledge in the paragraphs before his quotation, and the common sense generally, later. The Ciceronian term numeri refers to both the numbers in a word by word meaning, and to the rhythm of music, lecture, speech and other performances, metaphorically. It is mirrored in the English translations of Cicero. Reid's contemporary, William Guthrie (1708-1770) has translated Cicero's numeri in this locus as harmony:
"[But if any should be surprised that these things are discerned and marked by the most vulgar hearer; he needs but only reflect how great and incredible the force of na- ture is in every thing, especially in this;] for every man has within him a certain tacit sense, which enables him to distinguish what is right or wrong in arts and sciences, and this without instruction or information. If this observation holds good with re- gard to pictures, statues, [285] and other works, in criticising which, they have less assistances from nature, it is much more evident in the judgement they form upon words, harmony, and delivery, because this is a judgement implanted in the senses that are common to all mankind: it is a faculty, which nature never meant that any rational creature should be absolutely void of. Therefore, people are not only moved with an artful disposition of words, but ever with their harmony and sounds" (Cicero, 1822, pp. 284-285, my italics).

A 19th-century edition, translated by John Selby Watson (1804-1884) writes here numbers, using the second meaning of this word in plural, used in modern English, as well:

\footnotetext{
2 "Omnes enim tacito quodam sensu sine ulla arte aut ratione quae sint in artibus ac rationibus recta ac prava diiudicant; idque cum faciunt in picturis et in signis et in aliis operibus, ad quorum intellegentiam a natura minus habent instrumenti, tum multo ostendunt magis in verborum, numerorum vocumque iudicio; quod ea sunt in communibus infixa sensibus nec earum rerum quemquam funditus natura esse voluit expertem" (Cicero, 1822 , III. 1, pp. 195, 284-285, my italics).
} 
rhythm, or, metrical foot (Cicero, 1875, p. 250). The context of the understanding of rhetoric forms in the Ciceronian work has been evaporated in Reid's quotation, and refers to the both meanings of the abovementioned term. A human faculty for making culturally embedded aesthetical judgements and a faculty for calculate with numbers are the parts of the same continuum for Reid in here and for the Scottish common sense school in general. This Scottish semi-peripheral regard and the theories rooted in it have offered elements of the interpretation of a similar communicational turn of the philosophical public sphere on the Continent, especially in its semi-periphery, in Central and East-Central Europe.

At first it must be mentioned the case of the German philosophy in the middle of the 18th-century. German Populärphilosophie has focussed on the requirements of the audience of the new public philosophy, out of the walls of the universities, and other academic institutions. Populus as an audience is not identical with plebs, but a conscious community of responsible citizens, whose main characteristic is their urbanitas (see e.g. Ernesti, 1762, p. 153). The chain of ideas of the description of the ideal-typical audience has their roots in the concepts of politeness and refinement of the philosophy of SE, applied for the German case. The emphasis on the interaction of individuals in making - especially aesthetical - judgements, and the development of this new collectiveness is the main achievement of this school.

\section{I. Kant's description of the public sphere and J. G. Herder's analysis of the publicity}

Kant's reflections contain two main formulations, the distinction between philosophia in sensu scholastico and philosophia in sensu cosmopolitico, and between the private and public usage of one's (human) reason. However, Kant defines philosophia in sensu scholastico as a historical type of knowledge, it is clear that he is conscious of its institutional background. His formulation presumes an alternative system of institutions for philosophical knowledge. However, Kant always talks about the individuality of the usage of the reason; thinking has not lost actually its social aspects. The solution is hidden in the community; it is the publicity of thinking, or the liberty of the public usage of the human reason. Historians of philosophy rarely emphasise that the changed public sphere has enlarged the importance of national vernaculars in philosophical discourse. In Kant's cultural environment, in German philosophy the importance and the consequences of this change of languages were not clear at the first glance because of the highly large German-speaking audience of philosophy. In a more detailed analysis, 18th-century German reflections of the new structure of the academic public sphere mirror more difficult picture than a naive admiration of the new intellectual openness by the humans of this epoch. A distinguished German Kantian thinker, Professor Frederich Gottlob Born at Leipzig University, has written in his correspondence with Kant that the critical philosophy is a fundamental turn in the history of the Western philosophy, consequently its masterpieces should not remain in the domestic vernacular of the Germans, it must be available in Latin for the international audience. He has promptly developed and published the Latin translation of the main works of Kant's critical philosophy (1796-1798).

The native language of the new public philosophy and its consequences for the structure of its audience were hidden in the above discussed cases. Another concept of the same au- 
dience in the reflections of the next generation has focussed directly on this question. It is the historically well-developed concept of Publicum in Johann Gottfried Herder's Letters for the Advancement of Humanity (1795). The history of humanity and thinking is a chain of national communities as the units of communication in Herder's thought. They are special forms of audiences, by his term, Publicums (Herder has used the ancient form "Publicum", instead of "Publikum". For him, it was a classical Latin term and a common German word, at the same time; he has referred to the difference of the antique and modern public sphere). Herder was highly sensitive for the medial aspects of the historical forms of the audiences; his text is an obligatory reference for researchers of the turn of the thought of the oral and literary cultures; and it is a critique of the lack of the language in the thought of his master, Kant. However, in his investigations about the temporal and local types of the media-depended audience, Herder discusses a continuum within the actual audiences by genres and forms of the works from belles-lettres till the sciences and philosophy, controversy of the local vernacular and universal content of the philosophical work has not appeared as a problem for him, because of the structure of his concept of humanity. For a type of the theoretical analysis of the consequences of the circumstances of the new, urban(e) structure of public sphere of philosophy that has focused both on the changed structure of its audience as in the German Populärphilosophie and in the reflections of Kant, and on its changed language, as given by Herder, we should turn to the philosophical self-understanding of the East-Central European cultures.

\section{The controversy on I. Kant in the Hungarian philosophy, and the reflections to the public sphere during and after this debate}

In smaller East-Central European cultures the new structure of the public sphere has more clear consequences than in the above discussed English, Dutch and German cases: discourse on the "world philosophy" and the discourse about the role of some philosophical elements in national cultures have become evidently different; as it has become clear in the Hungarian case in the time of the controversy on Kant. Its first phase (1792-1800) was characterised by the dominantly Latin language, an endeavour for the participation in the European philosophical discourse and it was focused on the Kantian epistemology. The language of this debate has gradually turned to the Hungarian; and its argumentation has focused mainly on the ethics, after the first years of the 19th-century. The first phase was divided into two parts by the prohibition of the Kantianism in the Hapsburg Monarchy (1795); both parts are characterised by a Latin book written for the whole of the scholar community of Europe. The former one is Rozgonyi's Dubia de initiis transcendentalis idealism Kantiani (1792); the later one is Johann Baptiste Horváth's Declaratio infirmitatis fundamentorum operis Kantiani: Kritik der reinen Vernunft (1797). The international target audience of these works is clear on their frontispieces; Rozgonyi has dedicated his book for his German Kantian opponents ad Viros Clarissimos. Jacob et Reinhold; and it is the only book in Horvath's ceuvre, what was signed with his correspondent membership in Göttingen Academy of Sciences and Humanities, amongst his Hungarian affiliations and decorations: Reg. Scient. Societatis Götting. Membri Corresp. 
It is an interesting feature of this communicational turn that German has not become an alternative of the publication, as it has happened e.g. in Bohemia and Moravia, where the language of the philosophical publications has become German for a long time. Hungarian philosophers of this period have read the works of German philosophy in German, but their own opinions have published in Hungarian. Surprisingly, the golden age of the German classical philosophy was an epoch when publications written in German, because of their language, in Hungary have been gradually marginalised in the Hungarian philosophical life. András Mészáros has analysed this trend in his case study on the comparison of two Schellingian thinkers of the same generation, both of them native Hungarian speakers. One of them, István Nyiri has become a recognised Hungarian philosopher and a regular member of the Hungarian Academy of Sciences (HAS) because his writings were written in Hungarian. The other one, with similar institutional background, and with similar philosophical results, Mihály Petőcz has just achieved a marginal position in the Hungarian philosophical life, because he produced German publications. As Mészáros concludes:

"However, Petőcz has discussed the same problems as other Hungarian philosophers, but could not become a Hungarian philosopher, because he did not fulfil the most important requirement, the Hungarian language of his publications" (2012, p. 145).

It is an important coincidence of the history of the Hungarian philosophy in this epoch that the communicational turn from the narrow (but international) scholar discourse to the wider (but national) public sphere and from Latin to Hungarian has happened in the middle of the controversy on Kant. The Kantian controversy was the first Hungarian philosophical discussion in the realm of public philosophy, out of the institutional network of the universities and churches. Because of this coincidence and because of the plausibility of Kant's above discussed description of the structure of the new public sphere of scholars, self-understanding of the Hungarian philosophy was formulated at first in specially applied Kantian terms. It is late, but the clearest example is a discussion of the Department of Philosophy of the HAS about the concept of the Hungarian philosophy (Szilasy, 1847). By the proposal, between the Kantian world and school philosophies there must be two additional forms: the personal or individual philosophy, what is more than a school philosophy, but lacks the ambition of system-creation, and the national philosophy, whose aims are the same like that of the philosophy from a cosmopolitan view, but has remained in the realm of a native vernacular, and a national culture (world philosophy, "világphilosophia" was an equivalent of the Kantian philosophia in sensu cosmopolitico in the vocabulary of the Hungarian philosophy in this epoch). In the description of the aimed functions, characteristics and ideal-typical target audience of this public philosophy in a national language, it can be observed both the abovementioned Kantian and Herderian ideas in the special concept of national philosophy in sensu cosmopolitico, as a framework. The core of the content of the self-interpretation of the Hungarian public philosophy of the "long $19^{\text {th }}$ century" within these unified Kantian and Herderian frames has remained the ideal-typical urbanity of philosophy based on the Scottish tradition discussed above. In this period, it should be took into consideration the combination of the direct influence of the Scottish common sense philosophy and its transfer via the German Populärphilosophie, combined by the Kantian and Herderian concepts of publicity. 
It has appeared in symbolic forms like the reform of the philosophical life based on the method of Socrates as the par excellence urban philosopher in the program of the above mentioned Rozgonyi, the anti-Kantian protagonist of the Hungarian debate on Kant (Rozgonyi, 1808, it can be seen in the edited text of his inauguration lecture held in the College of Sárospatak in 1798). Rozgonyi's philosophical opinions have met that of the Scottish common sense school, which were familiar for him. In his most serious works he has referred his Scottish masters directly, and in his educational and popular writings he has added the well-known topics of Populärphilosophie to the same line of argumentation. There was a distinguished significance of the influence of Moses Mendelssohn: his opinions have appeared e.g. with a reference to his name in the published list of the questions of the philosophical exams of several Calvinist schools, e.g.: "Argumentum Cartesii a priore pro existential Dei \& Mendelsohnii [sic!] ex imperfectione cognitionis nostri, paralogismo laborant” (N. N., 1794, p. 29).

It is symptomatic that Mendelssohn's collected works were published at first in Hungary (1819a, 1819b, 1819c, 1819d, 1819e, 1819f, 1819g, 1819h, 1819i, 1819j, 1819k, 1819l). Later, an important discussion about the dominant literary genre of the modern age, is full of the analyses of the characteristics of the new urban(e) public sphere and the audience of the national culture in it. It is symptomatic that the initial writing refers directly to the Scottish common sense tradition in the person of Hugh Blair actually, to the Continental revival of this school, after the 19th-century translations in French, and later, in other languages: the opportunity for the so-called "controversy on epoch of epic versus epoch of drama" was offered by a book-review on the new Hungarian translation of Blair's Lectures on Rhetoric and Belles Lettres (Blair, 1838; Szontagh, 1839). In the controversy itself, the elements of the Populärphilosophie have appeared what were rooted in the same Scottish tradition, as well (For an analysis of the concept of urbanity of the German Populärphilosophie and its influence for the Hungarian culture, especially for the aesthetical discourse see Fórizs, 2009, pp. 55-71).

\section{Instead of the conclusions: the relationship of the national and urban cultures in the 19th-century Hungarian case}

In this writing it was offered, at first, a historical overview of the topics of the urbane spirit, urbanity, and their relationship with the scholar public sphere as the medium of philosophy from the Aristotelian and Ciceronian beginnings throw the theoretical reflections to the changed structure of the public sphere of the scholars, and to the new phenomenon of the public philosophy. This part of research was focussed on the early modern concept of the common sense as it has appeared in the 17th-18th-century British thought, especially in the tradition of the SE, and its reception in the German Populärphilosophie. After that, there were discussed the Kantian and Herderian reflections to the special Continental form of the same turn of the structure of the public sphere, with the consequences of the change of the language of the philosophical publications from Latin to the national languages.

The high importance of the language of philosophy was analysed in the Hungarian case, in the framework of an overview of the Hungarian theoretical reflections with their connections to all the above mentioned discourses, and in an interpretation of a special East-Central European form of the public philosophy, called national philosophy. In the Hungarian case 
the importance of the topics of urban sphere, urbanity, and the formulation of the roles of the cities was in the establishment of the new, modernised political community, namely the nation with its culture. The modernised Hungarian national culture in this discussion has appeared both as a product and a creator of this new, urban sphere; national and urban, nation and progress has existed in an optimistic harmony of the minds of the 19th-century authors. Under conditions of the critique of the modernity, emerged in the next century, this harmony of national and urban, nation and city has destroyed (for the details of the critique of modernity in the 20th-century Hungarian culture, see Kovács, 2017).

In spite of this fragile equilibrium between the positive and negative elements of the evaluation of the urbanity, and the role of the cities in the national development in the 19th-century Hungarian thought; it seems that several elements of an urban, technophile project, and a criticism of the modernity, developed in details in the 20th century, were ready in a nutshell as early as the first half of the 19th century. A monograph on the role of the cities, written by a paradigmatic author of the Hungarian Reform Era (HRE, 1825-1848), János Hetényi (1786-1853), offers an opportunity for a detailed analysis of this phenomenon (1841). Hetényi was a Calvinist pastor, and a significant public intellectual of the HRE. He was elected for the correspondent (1836) and regular (1840) membership of the Department for Philosophy of the HAS, and he was a regular winner of the academic awards of historiography, in the same time. Based on his position between political-social historiography and history of philosophy, an analysis of his work can describe a 19th-century philosophical opinion of the urbanity, and its connection with the modernisation of the nation as a political and cultural community, combined the data of the history. This analysis must be the next topic of the present research project, worthy for a separate article.

\section{References}

Aristoteles. (1872). Aristoteles' Politik. Berlin: Verlag von Wilhelm Hertz.

Aristotle. (2013). Aristotle's politics. Chicago and London: The University of Chicago Press.

Blair, H. (1838). Rhetorikai és Aesthetikai leczkéi. Buda: Magy. Kir. Egy.

Cicero. (1877). Cicero's Tusculan disputations; also, treatises on the nature of the gods, and on the commonwealth. New York: Harper \& Brothers, Publishers.

Cicero, M. T. (1822). M. T. Cicero de oratore: or, his three dialogues upon the character and qualifications of an orator. W. Guthrie (Ed.). Boston: R. P. and C. Williams.

Cicero. (1875). On oratory and orators. J. S. Watson (Ed.). New York: Harper \& Brothers, Publishers.

Cicero. (1853). Tusculanae disputationes. Jena: Frommann.

Ernesti, J. A. (1762). Opuscula oratoria, orationes, prolusiones et elogia. Lugduni Batavorum: S. and J. Luchtmans typs.

Fórizs, G. (2009). „Álpeseken Álpesek emelkednek”: A képzés eszménye Berzsenyi elméleti szövegeiben. Budapest: Universitas Kiadó.

Harrison, J., \& Laslett, P. (1971). The library of John Locke. Oxford: Clarendon Press.

Hennert, J. F. (1781). Aphorismi philosophici, scholis privatis accommodati. Stuttgart: Van Paddenburg.

Herder, J. G. (1795). Haben wir noch das Publicum der Alten?. In J. G. Herder, Briefe Beförderung der Humanität (pp. 56-124). Bd. 5. Riga: Hartknoch. 
Hetényi, J. (1841). Honi városaink befolyásáról nemzetünk’ kifejlődésére és csinosbulására. Budán: a’ Magyar kir. Egyetem' betüivel.

Horváth, J. B. (1797). Declaratio infirmitatis fundamentorum operis Kantiani: Kritik der reinen Vernunft. Budae: Typis Regiae Universitatis Pestiensis.

Kant, I. (1905). De mundi sensibilis atque intelligibilis forma et principiis. In I. Kant, Gesammelte Schriften [Akademische Ausgabe=AA] (pp. 385-416). Bd. 2. Berlin: Reimer.

Kant, I. (1902a). Meditationum quarundam de igne succincta delineatio. In I. Kant, Gesammelte Schriften [Akademische Ausgabe=AA] (pp. 3690-384). Bd. 1. Berlin: Reimer.

Kant, I. (1902b). Principiorum primorum cognitionis metaphysicae nova dilucidatio. In I. Kant, Gesammelte Schriften [Akademische Ausgabe=AA] (pp. 385-416). Bd. 1. Berlin: Reimer.

Kant, I. (1902c). Metaphycicae cum geometria iunctae usus in philosophia naturali, cuius specimen I. continet monadologiam physicam. In I. Kant, Gesammelte Schriften [Akademische Ausgabe=AA] (pp. 473-487). Bd. 1. Berlin: Reimer.

Kantii, I. (1796-1798). Opera Ad philosophiam criticam. Vols. I-IV. Lipsiae: Engelhard Ben Schwickert.

Kovács, G. (2017). From the guilty city to the ideas of alternative urbanization and alternative modernity: anti-urbanism as a border-zone of city-philosophy and cultural criticism in the interwar Hungarian political thought. Coactivity: Philosophy, Communication, 25, 99-109. https://doi.org/10.3846/cpc.2017.282

Locke, J. (1689). Epistola de tolerantia. Gouda: Justum ab Hoeve.

Mendelssohn, M. (1819a). Sämmtliche Werke. Vol. 1: Phädon, oder über die Unsterblichkeit der Seele. Ofen: Burian.

Mendelssohn, M. (1819b). Sämmtliche Werke. Vol. 2: Philosophische Schriften Erster Theil. Ofen: Burian.

Mendelssohn, M. (1819c). Sämmtliche Werke. Vol. 3: Philosophische Schriften Zweyter Theil. Ofen: Burian.

Mendelssohn, M. (1819d). Sämmtliche Werke. Vol. 4: Kleine Philosophische Schriften. Mit einer Skizze seines Lebens und Charakters von D. Jenisch. Ofen: Burian.

Mendelssohn, M. (1819e). Sämmtliche Werke. Vol. 5: Jerusalem, oder über religiöse Macht und Judenthum. Ofen: Burian.

Mendelssohn, M. (1819f). Sämmtliche Werke. Vol. 6: Morgenstunden; Vorlesungen über das Daseyn Gottes. Ofen: Burian.

Mendelssohn, M. (1819g). Sämmtliche Werke. Vol. 7: Ritualgesetze der Juden Betreffend Erbschaften, Vormundschaften, Testamente und Ehesachen in so weit sie das Mein und Dein angehen. Entworfen von Moses Mendelssohn, auf Veranlassung und unter Aufsicht R. Hirschel Lewin, Oberrabbiners zu Berlin. Ofen: Burian.

Mendelssohn, M. (1819h). Sämmtliche Werke. Vol. 8: Die Psalmen. Ofen: Burian.

Mendelssohn, M. (1819i). Sämmtliche Werke. Vol. 9: Gelehrter Briefwechsel zwischen D. Johann Jacob Reiske, Moses Mendelsshon und Gotthold Ephraim Lessing. Ofen: Burian.

Mendelssohn, M. (1819j). Sämmtliche Werke. Vol. 10: Abhandlung über die Evidenz in metaphysischen Wissenschaften. Ofen: Burian.

Mendelssohn, M. (1819k). Sämmtliche Werke. Vol. 11: M. M. an die Freunde Lessings. Ein Anhang zu Herrn Jacobi Briefwechsel über die Lehre des Spinoza. Ofen: Burian.

Mendelssohn, M. (1819l). Sämmtliche Werke. Vol. 12: Manasseh Ben Israel Rettung der Juden. Ofen: Burian.

Mester, B. (2010). Censorship as a typographical chimera: John Milton and John Locke on Gestures. Synthesis Philosophica, 50(2), 211-219.

Mészáros, A. (2012). Ki lehetett magyar filozófus az 1830-as években? (esettanulmány). In D. Gurka (Ed.), Tudósok a megismerés színterein: a romatikus tudományok és a 18-19. századi tudóssztereotípiák (pp. 134-146). Budapest: Gondolat. 
N. N. (1794). Philosophiae studiosi sub praesidio clarissimi viri Iosephi Rozgonyi. Novi Ecclesiasticoscholastici Annales evangelicorum augustanae et helveticae confessionis in Austriaca Monarchia, 2(1), 29-30.

Reid, Th. (1786). Essays on the intellectual powers of man. Vol. II. Dublin: L. White.

Rozgonyi, J. (1819). A’ Pap es a’ Doctor a' sinlődő Kánt körül, vagy rövid vizsgálása, fóképen a' Tiszt. Pucz Antal Ur' Elmélkedéseinek: A' Kánt' Philosophiájának fö Resultatumairol, 's óldalaslag illetése az erköltsi Catechismust Iró' Bétsi feleleteinek. S. Patak: Nádaskay.

Rozgonyi, J. (1792). Dubia de initiis transcendentalis idealism Kantiani. Pestini: Matthiae Trattner.

Rozgonyi, J. (1808). Oratio inauguralis de Socratica philosophandi ratione nostris temporibus revocanda. S. Patakini: Josephi Szentes.

Shaftesbury, Third Earl of A. (1737). Sensus Communis; An essay on the freedom of wit and humour. In Third Earl of Shaftesbury, A. Characteristicks of men, manners, opinions, times. Vol. 1 (pp. 37-94). Indianapolis: Liberty Fund, Inc.

Smith, A. (1976). The theory of moral sentiments. D. D. Raphael \& A. L. Macfie (Eds.). Oxford: Clarendon Press.

Szilasy, J. (1847). Lehet-e magyar philosophia?. Magyar Akadémiai Értesitő, 7(6), 152-154.

Szontagh, G. (1839). Blair Hugo’ rhetoricai és aestheticai leczkéi. Figyelmezö, 3(19), 305-310.

Woolf, V. (2006). Orlando: a biography. M. Hussey (General Ed.). Orlando: A Harvest Book, Harcourt, Inc.

\section{Note}

This article has been written within the framework of the bilateral research project managed by the Department of Philosophy and Communication of the Faculty of Creative Industries of the Vilnius Gediminas Technical University, Vilnius, Lithuania, and by the Institute of Philosophy of the Research Centre for the Humanities of the HAS, Budapest, Hungary, sponsored by the Lithuanian Academy of Sciences, and the HAS. The text of the present writing is based on the lectures held by the same author, entitled The Emergence of the Public Philosophy in the East-Central European Urban(e) Cultures; and Cities, National Cultures, and National Philosophies in the Past of East-Central Europe. These lectures were read by the opportunity of a workshop and a conference organised within the framework of the above mentioned Lithuanian-Hungarian research project on October 17th, 2016 in Vilnius, and on December 6th, 2016 in Budapest.

\section{MIESTAI KAIP KŪRYBIŠKUMO CENTRAI FORMUOJANT RYTŲ IR VIDURIO EUROPOS TAUTĄ}

\section{Béla MESTER}

\section{Santrauka}

Šiame straipsnyje pateikiamos XVIII ir XIX amžių filosofinès refleksijos, skirtos viešosios mokslininkų aplinkos struktūros kaitai. Remiantis Vengrijos pavyzdžiais, dèmesys sutelkiamas ị miestietiškumo idejją. Aptarus Škotijos Apšvietą bei kantiškąjị ir herderiškąji požiūrius, svarstomas Vengrijos atvejis Immanuelio Kanto kontroversijos 
(1792-1822) metu ir po jos. Urbanitas temos dažnai imtasi tiek kaip idealios-tipiškos filosofinès veiklos aplinkos, tiek kaip realios autorių aplinkos industrializuotos kultūros produkcijos mašinerijos sąlygomis. Kita tema - specifiniai to paties struktūros posūkio mokslininkų komunikacijos bruožai Rytų ir Vidurio Europoje, kur publikacijų kalbų pokytis turi būdingų pasekmių, o atotrūkis tarp mokyklinès filosofijos ir viešosios filosofijos vis gilejja. Rytų ir Vidurio Europos filosofijos šakų savipratos bruožai naujame kontekste po komunikacijos pokyčio - tai paskutinė tema. Dėmesys sutelkiamas ị Vengrijos atvejî, ypač ị miestietiškumo koncepto vartoseną vengriškajame kūrybiniame diskurse apie viešają filosofija ir tautinę filosofiją.

Reikšminiai žodžiai: Rytų ir Vidurio Europa, vengrų filosofija, tautinè filosofija, viešoji filosofija, miesto sritis, miestietiškumas. 